\title{
LYMPHOEPITHELIAL CARCINOMA OF THE PALATINE TONSIL
}

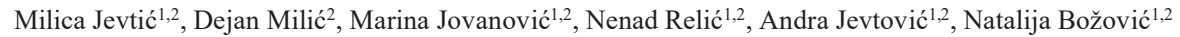

${ }^{1}$ University of Kragujevac, Faculty of Medical Sciences, Department of Otorhinolaryngology, Kragujevac, Serbia ${ }^{2}$ Clinical Centre Kragujevac, Clinic of Otorhinolaryngology, Kragujevac, Serbia

\section{LIMIFOEPITELIJALNI KARCINOM PALATINALNE TONZILE}

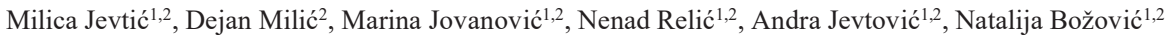

${ }^{I}$ University of Kragujevac, Faculty of Medical Sciences, Department of Otorhinolaryngology, Kragujevac, Serbia ${ }^{2}$ Clinical Centre Kragujevac, Clinic of Otorhinolaryngology, Kragujevac, Serbia

\begin{abstract}
Lymphoepithelial carcinoma is an undifferentiated carcinoma with nonneoplastic lymphoplasmacytic infiltrate, mostly located in the nasopharynx, while it is extremely rare in the oropharynx. We present a rare case of lymphoepithelial carcinoma arising from palatine tonsil. A 81-year old male patient complained of dysphagia, hypersalivation and bloody sputum. Clinical examination revealed hypertrophy of the right palatine tonsil and ipsilateral cervical lymphadenopathy. Biopsy and histopathological analysis confirmed the diagnosis of lymphoepithelial carcinoma. Multi-slice computed tomography showed a $33 \times 31 \times 38 \mathrm{~mm}$ heterodense mass in the region of the right palatine tonsil, and $37 \times 30 \mathrm{~mm}$ and $21 \times 20 \mathrm{~mm}$ lymph nodes on the right side of the neck. The patient was reffered to an oncology council, which suggested radiotherapy and concurrent chemotherapy. Although rare in clinical practice, lymphoepithelial carcinoma should be considered in cases of tonsil cancer.
\end{abstract}

Keywords: oropharyngeal cancer, palatine tonsil, lymphoepithelial, squamous cell, undifferentiated.

\section{SAŽETAK}

Limfoepitelijalni karcinom predstavlja nediferentovani karcinom sa neneoplastičnom limfoplazmocitnom komponentom. Najčešće se javlja u nazofarinksu, dok je u orofarinksu izuzetno redak. Predstavljamo redak slučaj limfoepitelijalnog karcinoma palatinalne tonzile. 81-ogodišnji pacijent javio se zbog disfagije, hipersalivacije i krvavog sputuma. Kliničkim pregledom utvrđena je hipertrofija desne tonzile i ipsilateralna cervikalna limfadenopatija. Biopsijom i patohistološkim nalazom potvrđena je dijagnoza limfoepitelijalnog karcinoma tonzile. Multi-slajsna kompjuterizovana tomografja pokazala je prisustvo heterodenzne tumorske mase u desnoj tonzili, dimenzija oko $33 \times 31 \times 38 \mathrm{~mm}$, kao i uvećanje dva limfonodusa na desnoj strani vrata, dimenzija oko $37 \times 30 \mathrm{~mm}$ i $21 \times 20 \mathrm{~mm}$. Pacijent je prikazan onkološkom konzilijumu koji je predložio sprovođenje radioterapije uz hemiopotencijaciju. Iako redak histološki tip karcinoma tonzile u kliničkoj praksi, treba misliti i na ovu vrstu tumora.

Ključne reči: orofaringealni karcinom, palatinalna tonzila, limfoepitelijalni, skvamocelularni, nediferentovani.

\author{
ABBREVIATIONS \\ EBV- Epstein-Barr virus \\ ENT- ear, nose and throat \\ LEC- lymphoepithelial carcinoma \\ SCC- squamous cell carcinoma \\ UCNT- undifferentiated carcinoma of nasopharyngeal type
}




\section{INTRODUCTION}

Head and neck cancers are the 6th most common malignancy worldwide.(1) Squamous cell carcinoma (SCC) represents $90 \%$ of head and neck cancers, predominantly affecting mucosal lining of oral cavity, oropharynx and larynx.(2) Between $70 \%$ and $80 \%$ of oropharyngeal SCC are located in the palatine tonsil.(3) Lymphoepithelial carcinoma (LEC) is a particular histological type, defined as an undifferentiated carcinoma, accompanied by reactive lymphoplasmacytic infiltrate. It is mostly located in the nasopharynx, where it is called undifferentiated carcinoma of nasopharyngeal type (UCNT).(4) We present a rare case of LEC of the palatine tonsil in 81-year old male patient.

\section{CASE REPORT}

A 81-year old male patient was admitted to our clinic due to dysphagia, hypersalivation and bloody sputum. Dysphagia was present for 2 months prior to hospitalization, which had been gradually worsening, while hypersalivation was present for 8 months. Bloody sputum appeared 3 days before hospitalization. The patient is a nonsmoker and does not drink. Oropharyngoscopy revealed significant hypertrophy of the right palatine tonsil, partly covered with white deposits and pushing the uvula towards the opposite side (Figure 1). Neck examination showed a firm non-tender mass in region II of the right side of the neck (Figure 2).

We performed incisional biopsy of the right tonsil. Histopathology analysis revealed tissue sample with preserved covering epithelium, with sheets and islands of polymorphic and polygonal cells, vesicular nuclei, dispersed chromatin, noticeable pathological mitosis and areas of geographic necrosis. Immunohistochemistry analysis showed an expression of p63 and Epstein-Barr virus (EBV. Histopathology and immunohistochemistry reports confirmed the diagnosis of undifferentiated carcinoma of nasopharyngeal type (UCNT), or in other words LEC.

Figure 1. Oropharyngoscopy showing significant hypertrophy of the right palatine tonsil.

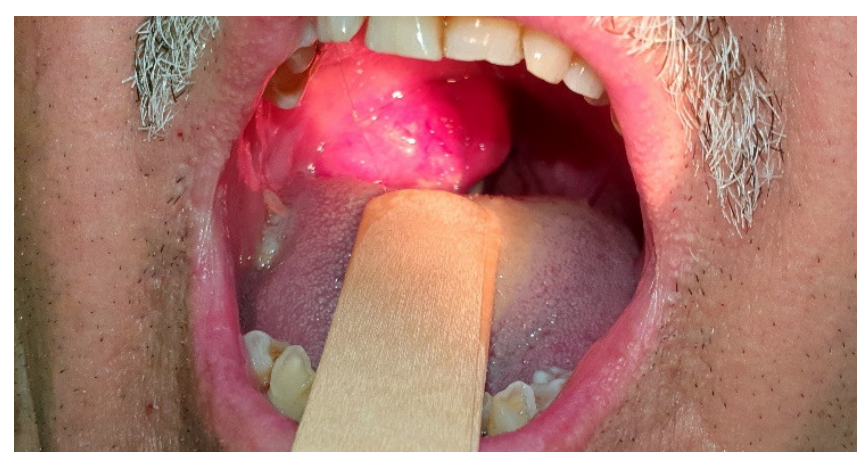

Figure 2. Neck examination showing regional cervical lymph node metastases in the region II of the neck.

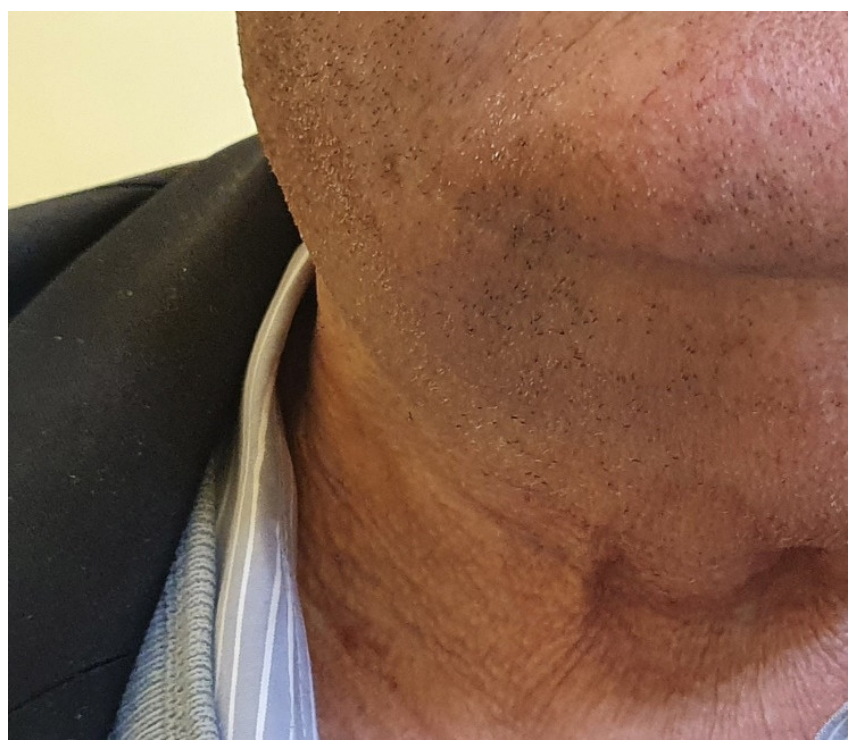

Figure 3. Multi-slice computed tomography showing a heterodense mass in the right palatine tonsil, extending toward the lingual side of the epiglottis

(arrows showing the tumor).

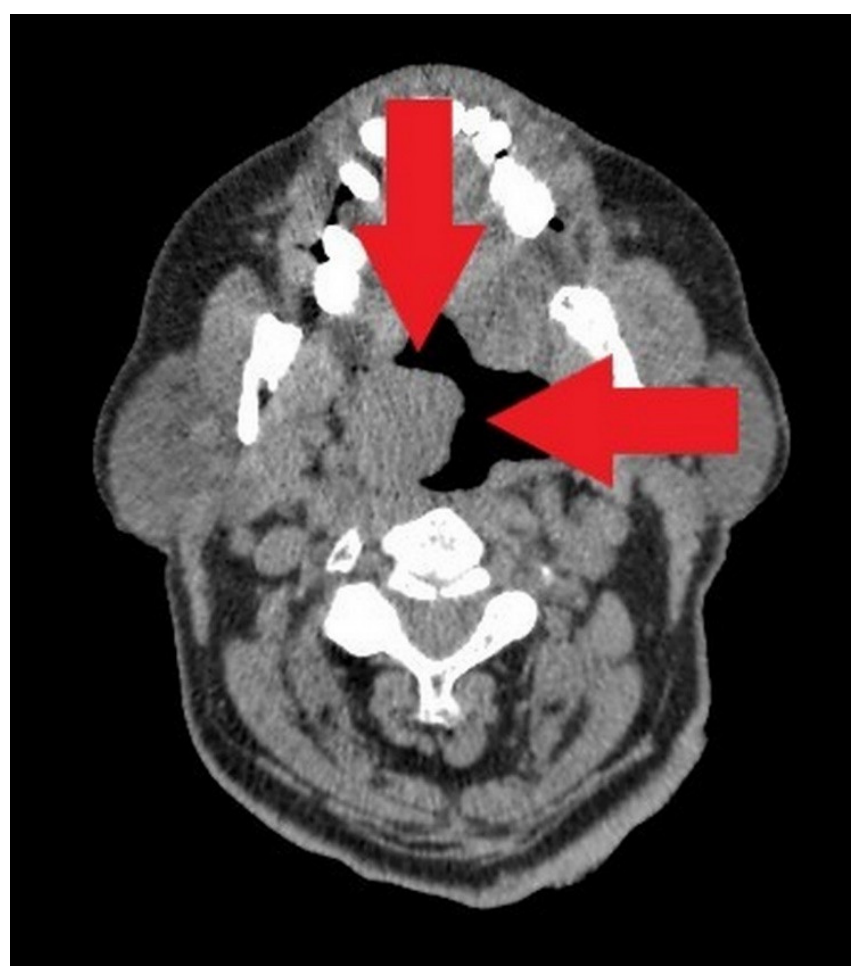


Figure 4. Chest X-ray showing no abnormalities.

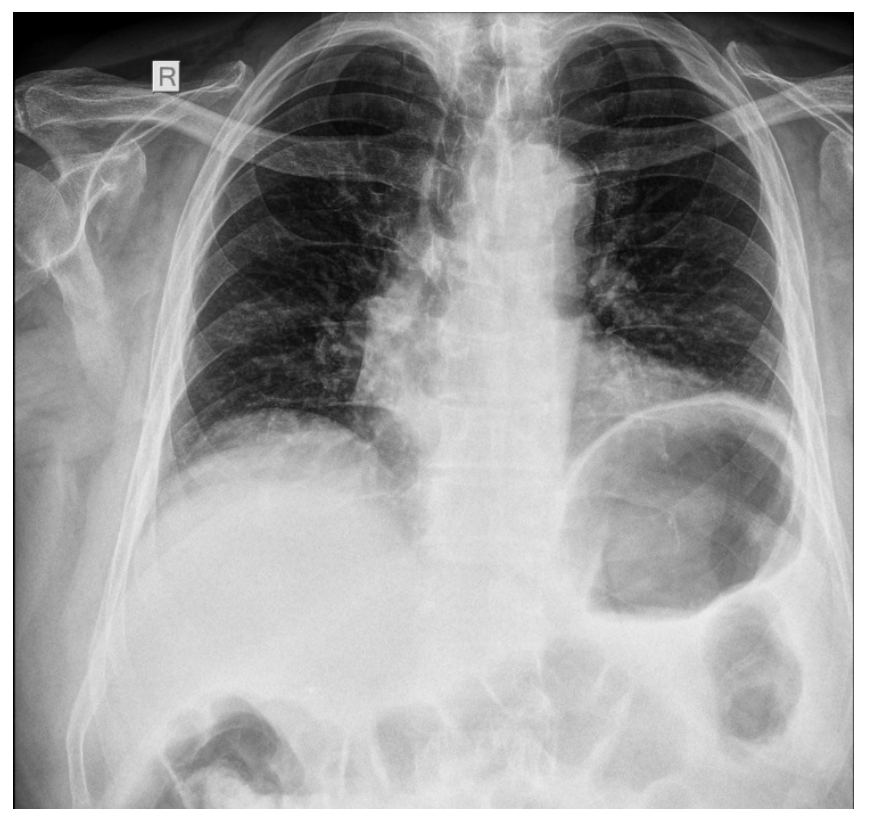

Multi-slice computed tomography detected a $33 \times 31 \times 38$ $\mathrm{mm}$ heterodense mass of the right tonsil, extending toward the lingual side of the epiglottis, as well as $37 \times 30 \mathrm{~mm}$ and $21 \times 20 \mathrm{~mm}$ lymph nodes on the right side of the neck (Figure 3 ). Chest X-ray showed no abnormalities (Figure 4). Considering the histological type and local and regional spread of the tumor, the patient was referred to an oncology council, which decided upon radical radiotherapy and chemotherapy potentiation once a week during radiotherapy. The patient was advised to come in for a follow-up 1 month after the oncology treatment.

\section{DISCUSSION}

SCC accounts for more than $95 \%$ of oropharyngeal cancers.(5) Among these, a particular histological type is LEC, morphologically identical to undifferentiated nonkeratinizing nasopharyngeal cancer (UCNT, earlier known as WHO type 3$).(3,6)$ LEC is very rare in the oropharynx and oral cavity, where it represents only $0,8-2 \%$ of all cancers. In more than $90 \%$ of cases, LEC is located in the palatine tonsil or the base of the tongue, (7) as in our case. $75 \%$ of LEC arise from the nasopharynx, where it represents $40 \%$ of all tumors and is almost exclusively related to EBV, which was immunohistochemically proved in our case. Outside of the nasopharynx, LEC is considerably more rare, usually occuring in young males and in more advanced stage compared to nasopharyngeal LEC.(8)

Known risk factors for tonsil cancer are tobacco smoking and alcohol consumption, acting individually and synergistically.(9) However, our patient was a nonsmoker and a nondrinker. Even though tobacco and alcohol use have significantly decreased in the past 50 years, incidence rates for oropharyngeal cancers have increased. Possible explanation is human papillomavirus infection, which is present in up to $47 \%$ of oropharyngeal cancers.(10)

Clinical manifestations of tonsil cancer include sore throat, globus sensation, ipsilateral ear pain, dysphagia, odynophagia and trismus as a sign of local invasion. $(11,12) \mathrm{Up}$ to $60 \%$ of cases present with regional lymph node metastases upon first examination.(5) Our patient complained of dysphagia, hypersalivation and bloody sputum. Hypersalivation was secondary to dysphagia and accumulation of saliva in the mouth, while blood in the sputum was a result of tumor haemorrhage.

Diagnosis of tonsil cancer is based on anamnesis, clinical ENT examination, radiology imaging methods and histopathology analysis.(11) Clinical examination revealed notable enlargement of the right palatine tonsil, partially covered with white deposits, pushing the uvula toward the left side and cervical lymphadenopathy on the side of the enlarged tonsil. Tonsil asymmetry, id est unilateral tonsil hypertrophy, can be the only sign of disease in otherwise asymptomatic patients and the reason for an ENT referral.(12) Among imaging methods, computed tomography is the method of choice, used for estimating the tumor size and its regional and distant spread.(11,12) Histopathology analysis is necessary for definitive diagnosis. Histological characteristics of LEC include the presence of lobules, sheets or islands of polygonal or spindle-shaped tumor cells, round or oval, vesicular nuclei with moderate to marked nuclear pleomorphism, as well as nonneoplastic lymphoplasmacytic cell infiltrate between tumor cells. Increased mitotic activity and necrosis are also frequently found. Immunohistochemistry analysis shows reactivity for cytokeratins and epithelial membrane antigen, focal or diffuse reactivity for p63, while in situ hybridization shows presence of EBV.(4) These characteristics were present in our case.

Treatment for tonsil cancer includes surgery, radiotherapy and chemotherapy. The choice of therapeutic modality depends on TNM staging.(13) The course of action for early cases of the disease is monomodality, either surgery or radiotherapy.(9) Unfortunately, only $1 / 3$ of cases are diagnosed in the early phase.(14) Due to cancer radiosensitivity, radiotherapy combined with concurrent chemotherapy or with surgery for residual disease are applied in advanced cases,(13) as were in our case.

\section{CONCLUSION}

Lymphoepithelial carcinoma is a rare histological entity and is typically found in the nasopharynx, very rarely in the oropharynx and tonsils. Risk factors for this cancer include tobacco and alcohol use, Epstein-Barr virus infection mostly in the endemic regions and human papillomavirus infection. Although a rare histological type, lymphoepithelial carcinoma should always be considered in cases of tonsil cancer in clinical practice. 


\section{LITERATURE}

1. Solomon B, Young RJ, Rischin D. Head and neck squamous cell carcinoma: Genomics and emerging biomarkers for immunomodulatory cancer treatments. Semin Cancer Biol. 2018;52:228-40.

2. Winquist E, Agbassi C, Meyers BM, Yoo J, Chan KKW. Systemic therapy in the curative treatment of head and neck squamous cell cancer: a systematic review. J Otolaryngol - Head Neck Surg. 2017;46(1):1-11.

3. Ahmadi N, Chan M, Ruth Y, Sritharan N, Chin RY. Survival outcome of tonsillar squamous cell carcinoma (TSCC) in the context of human papillomavirus (HPV): A systematic review and meta-analysis. Surg. 2019; 17(1):6-14.

4. Wenig BM. Lymphoepithelial-like carcinomas of the head and neck. Semin Diagn Pathol. 2015;32(1):74-86.

5. Fossum CC, Chintakuntlawar A V, Price L, Garcia JJ. Characterization of the Oropharynx: Anatomy, Histology, Immunology, Squamous Cell Carcinoma \& Surgical Resection. Histopathology. 2017;70(7):10219.

6. Rytkönen AE, Hirvikoski PP, Salo TA. Lymphoepithelial Carcinoma: Two Case Reports and a Systematic Review of Oral and Sinonasal Cases. Head Neck Pathol. 2011;5(4):327-34.

7. Barnes L, Eveson JW, Reichart P, Sidransky D. World Health Organization Classification of Tumours Pathology \& Genetics Head and Neck Tumours IARC WHO Classification Head and Neck Tumours. 2005.

8. Bai J, Zhao F, Pan S. Clinicopathological characteristics and survival of lymphoepithelial carcinoma of the oral cavity and pharynx: a population-based study. BioRxiv. 2019;669671.

9. Laccourreye O, Rubin F, Badoual C, Halimi P, Giraud $\mathrm{P}$. The keys to conservative treatment of early-stage squamous cell carcinoma of the tonsillar region. Eur Ann Otorhinolaryngol Head Neck Dis [Internet]. 2017;3-8. Available from: http://dx.doi.org/10.1016/j.anorl.2017. 03.007

10. De Santis S, Spinosi MC, Cambi J, Bengala C, Boccuzzi $\mathrm{S}$. Oropharyngeal squamous cell carcinoma and HPV. Systematic review on overall management. J Stomatol Oral Maxillofac Surg. 2017;118(2):103-8.

11. Jamal Z, Anjum F. Oropharyngeal Squamous Cell Carcinoma Histopathology. StatPearls Publ. 2020.

12. Williamson AJ, Mullangi S, Gajra A. Tonsil Cancer. StatPearls Publ. 2020.
13. Marur S, Forastiere AA. Head and Neck Squamous Cell Carcinoma: Update on Epidemiology, Diagnosis, and Treatment. Mayo Clin Proc. 2016;91(3):386-96.

14. Economopoulou P, de Bree R, Kotsantis I, Psyrri A. Diagnostic tumor markers in head and neck squamous cell carcinoma (HNSCC) in the clinical setting. Front Oncol. 2019;9:827. 